\title{
PEMBELAJARAN STATISTIKA DALAM PERSPEKTIF GENDER
}

\section{Yuyun Yunarti}

Institut Agama Islam Negeri (IAIN) Metro

JL. Ki Hajar Dewantara No.15A, Iringmulyo, Metro Timur, Kota Metro, Lampung

Email: yuyunyunarti300977@gmail.com

\begin{tabular}{|c|c|c|}
\hline Diterima: & Revisi: & Disetujui: \\
23 Agustus 2018 & 08 Oktober 2018 & 19 November 2018 \\
\hline
\end{tabular}

\begin{abstract}
Statistics is considered a boring subject for students, even though statistics are taught with the aim of preparing students to be able to use statistics in their daily lives. In studying statistics, there are still many students both men and women who view statistics as a boring subject. Based on this, the gender aspects of statistical learning are of concern to educators. Gender differences not only result in differences in abilities in statistical courses, but also in obtaining statistical knowledge. Many opinions say that women are not enough to successfully study statistics compared to men. In addition, women almost never have a thorough interest in theoretical questions like men. Women are more interested in practical things than theoretical ones. But on the other hand, not a few female students have success in statistical abilities.
\end{abstract}

Keyword: gender, statistical learning, and statistical abilities

\begin{abstract}
Abstrak
Statistika dianggap sebagai mata kuliah yang membosankan bagi mahasiwa, padahal statistika diajarkan dengan tujuan untuk mempersiapkan peserta didik agar dapat menggunakan statistika dalam kehidupan sehari-hari. Dalam mempelajari statistika, masih banyak mahasiwa baik laki-laki maupun perempuan yang memandang statistika merupakan mata kuliah yang membosankan.Berdasarkan hal tersebut, aspek gender dalam pembelajaran statistika menjadi perhatian kalangan pendidik. Perbedaan gender bukan hanya berakibat pada perbedaan kemampuan dalam mata kuliah statistika, tetapi juga caramemperoleh pengetahuan statistika. Banyak pendapat yang mengatakan bahwa perempuan tidak cukup berhasil mempelajari statistika dibandingkan dengan laki-laki. Selain itu, perempuan hampir tidak pernah mempunyai ketertarikan yang menyeluruh pada soal-soal teoritis seperti lakilaki. Perempuan lebih tertarik pada hal-hal yang praktis dari pada yang
\end{abstract}


teoritis. Namun di lain pihak, tidak sedikit mahasiswa perempuan yang memiliki keberhasilan dalam kemampuan statistika.

Kata Kunci: gender, pembelajaran statistika, dan kemampuan statistika

\section{A. Pendahuluan}

Di peguruan Tinggi di Indonesia, statistika merupakan mata kuliah yang menjadi momok bagi mahasiswa. Statistika menjadi salah satu cabang ilmu dari statistika yang pada prinsipnya adalah mempelajari tentang pengumpulan, pengolahan dan penganalisisan data, serta penarikan kesimpulan berdasarkan hasil analisis data. Data yang digunakan dalam statistika merupakan data yang berupa angka atau disebut data kuantitatif. Oleh karena itu, bagi mahasiswa, mata kuliah statistika termasuk mata kuliah yang ditakuti, dijauhi, dan dianggap sulit seperti juga halnya pelajaran statistika, yang selalu dikatakan sebagai pelajaran yang paling sulit. Padahal, bagi mahasiswa mata kuliah statistika sangat penting karena akan sangat berguna ketika menyusun skripsi bagi mahasiswa $\mathrm{S} 1$, menyusun tesis bagi mahasiswa S2, dan menyusun disertasi bagi mahasiswa S3. Dalam hal ini, pengetahuan statistika dipakai dalam menyusun metode penelitian.

Dalam proses, Pendidikan mempunyai fungsi yang sangat penting bagi generasi penerus bangsa. Potensi mahasiswa dapat dikembangkan melalui aktifitas belajar di kampus, sehingga apa yang menjadi tujuan belajar dapat tercapai, yang terwujud dalam suatu prestasi belajar. Prestasi belajar sangat penting sebagai indikator keberhasilan baik bagi seorang dosen maupun mahasiswa. Kemampuan mengembangkan prestasi belajar mahasiswa tentu menjadi hal yang sangat penting bagi seorang dosen. Dosen dituntut untuk dapat menjadi dosen yang professional agar dapat menciptakan sumber daya manusia yang lebih baik di masa depan. Dalam mencapai hal itu, akan melibatkan mahasiswa dalam proses belajar yang mengarah pada tercapainya tujuan tersebut. Sumber daya manusia yang baik tercipta dari generasinya yang memiliki prestasi yang baik. 
Berdasarkan proses pembelajaran di kampus yang melibatkan mahasiswa laki-laki dan perempuan, banyak pendapat yang mengatakan bahwa mahasiswa perempuan tidak cukup berhasil dalam mempelajari di bidang ilmu pengetahuan di bandingkan lakilaki. Ada kecenderungan perbedaan kemampuan antara laki-laki dan perempuan dalam hal hasil belajar terutama di bidang statistika dan sains. Menurut Eriba dkk, menyatakan bahwa suatu kemerosotan apabila wanita menganggap mata pelajaran sains adalah milik pria. Sudah sejak lama pula cara pikir pria dan wanita dianggap berbeda, selama ini pria lebih dicirikan dengan cara pikir yang logis sedangkan wanita dengan cara pikir yang lebihmelibatkan emosi.

Banyak faktor yang harus diperhatikan dalam mempelajari statistika, antara lain kemauan, kemampuan, dan kecerdasan tertentu, kesiapan dosen, kesiapan mahasiswa, kurikulum, dan metode penyajiaannya, Faktor yang tak kalah pentingnya adalah faktor jenis kelamin mahasiswa (gender). Perbedaan gender tentu menyebabkan perbedaan fisiologi dan memengaruhi perbedaan psikologis dalam belajar. Sehingga Mahasiswa laki-laki dan perempuan tentu memiliki banyak perbedaan dalam mempelajari statistika. Menurut Susento perbedaan gender bukan hanya berakibat pada perbedaan kemampuan dalam statistika, tetapi cara memperoleh pengetahuan statistika. Keitel menyatakan "Gender, social, and cultural dimension sare very powerfully interacting in conceptualization of mathematics education,...".

Berdasarkan pendapat Keitel bahwa gender, sosial dan budaya berpengaruh pada pembelajaran Statistika. Brandon menyatakan bahwa perbedaan gender berpengaruh dalam pembelajaran statistika terjadi selama usia Perguruan Tinggi Dasar. Yoenanto dalam Nawangsari menjelaskan bahwa mahasiswa pria lebih tertarik dalam pelajaran statistika dibandingkan dengan mahasiswa wanita, sehingga mahasiswa wanita lebih mudah cemas dalam menghadapi statistika dibandingkan dengan mahasiswa pria.

Oleh karena itu aspek gender perlu menjadi perhatian khusus dalam pembelajaran statistika. Dengan kata lain perubahan proses 
pembelajaran statistika yang menyenangkan memperhatikan aspek perbedaan jenis kelamin sehingga mahasiswa laki-laki dan perempuan tidak lagi takut atau cemas dalam pelajaran statistika. Berkaitan dengan pembelajaran di Perguruan Tinggi yang melibatkan mahasiswa laki-laki dan perempuan, diharapkan tidak terjadi ketimpangan gender atau bias gender. Hal ini akan merugikan mahasiswa perempuan secara psikologis. Seperti yang diungkapkan olehFakihbahwa bias gender dapat diartikan pembentukan sifat atau karakter laki-laki dan perempuan secara sosial dan kultural yang menguntungkan kaum laki-laki dan merugikan kaum perempuan.

\section{B. Pembahasan}

1. Gender dan Pengertiannya

Gender dalam kamus bahasa Inggris berarti "jenis kelamin atau seks". ${ }^{1}$ Gender dalam ejaan bahasa Indonesia adalah gender. Sedangkan istilah gender menurut The Contemporary EnglishIndonesian Dictonary diartikan sebagai "penggolongan menurut jenis kelamin".2 Sedangkan dalam Webster College Dictionary, gender: "One of the categories in such a set, as masculine, feminisme, neuter, orcommon". 3

Di dalam Enclopedia Feminisme dijelaskan bahwa gender adalah kelompok atribut dan perilaku yang dibentuk secara kultural ada pada laki-laki atau perempuan. ${ }^{4}$ Di dalam Women's Studies Enclopedia yang dijelaskan bahwa gender adalah suatu konsep kultural yang berupaya memuat pembedaan dalam hal peran, perilaku, mentalitas, dan karakteristik emosional antara

1 John M. Echols dan Hassan Syadily, Kamus Inggris Indonesia, Cet XII, (Jakarta: Gramedia, 1983), h. 265

2 Peter Salim, The Contemporary English-Indonesian Dictionary, (Jakarta: Modern English Press, 1996), h. 771

3 Random House, Webster College Dictionary, (New York Toronto London Sydney Auckland, 2001), h. 511

4 Muhdirahayu (terj), Dictionary of Feminist Theories, (Jogjakarta: Fajar Pustaka Baru, 2002), h. 177 
pria dan wanita yang berkembang dalam masyarakat. ${ }^{5}$ Perlu dipahami terlebih dahulu bahwa seks lebih banyak berkonsentrasi kepada aspek biologis seseorang, meliputi perbedaan komposisi kimia dan hormon dalam tubuh, anatomi fisik, reproduksi dan karakteristik biologis lainnya. Seks atau jenis kelamin adalah perbedaan biologis antara laki-laki dan perempuan. Sedangkan gender lebih berkonsentrasi kepada aspek sosial, budaya, psikologi, dan aspek-aspek non biologis lainnya. Gender ini digunakan untuk mengidentifikasikan perbedaan laki-laki dan perempuan dari segi sosial budaya. Gender menjelaskan semua atribut, peran dan kegiatan yang terkait dengan "menjadi laki-laki" atau "menjadi perempuan". ${ }^{6}$

Jadi gender dan seks atau jenis kelamin sangat berbeda sekali, karena seks atau jenis kelamin bersifat alamiah, sedangkan gender peran dan fungsinya dibentuk oleh keadaan masyarakat, sosial dan budaya. Munculnya peran laki-laki dan perempuan dapat saling berganti. Dalam arti, perempuan tidak hanya berperan domestik, melainkan juga berperan publik. Laki-laki bukan hanya berperan publik, tetapi juga berperan domestik. Menurut Mansur Fakih, konsep gender adalah suatu sifat yang melekat kaum laki-laki maupun perempuan yang dikonstruksikan secara sosial maupun kultural, misalnya perempuan dikenal lemah lembut, cantik, emosional atau keibuan sementara laki-laki dianggap kuat, rasional, jantan dan perkasa. Ciri-ciri sifat itu sendiri merupakan sifat-sifat yang dapat dipertukarkan. Artinya ada laki-laki yang emosional, lemah lembut, sementara ada juga perempuan yang kuat, rasional, dan perkasa. Perubahan ciri dari sifat-sifat itu dapat terjadi dari waktu ke waktu dan dari tempat ke tempat yang lain.

\footnotetext{
${ }^{5}$ Hellen Tierney (ed), Women's Studies Inclopedia, vol I, (New York: Green Word Press), h. 153.

${ }^{6}$ Istibsyaroh, Hak-Hak Perempuan Relasi Gender Menurut Tafsir Al-Sya'rawi, (Jakarta: Teraju, 2004), h. 62
} 
Dalam al-Qur'an tidak ditemukan kata yang sepadan dengan istilah gender akan tetapi kata kunci yang dapat dipegang untuk mengetahui ayat-ayat gender ialah semua istilah yang sering digunakan untuk menyebut laki-laki dan perempuan seperti kata al-rijal (الرجال) dan an-nisa' (النساء), al-zakar (الذكر) dan al-untsa (نثال). Sementara itu, dalam mengungkapkan masalah tertentu al-Qur'an konsisten memakai istilah-istilah khusus. Seperti aspek biologis al-Qur'an sering menggunakan istilah aldzakar/male untuk laki-laki dan al-untsa/female untuk perempuan. Sementara dalam aspek gender al- Qur'an sering menggunakan istilah al-rojul/al-rijal untuk menyebut jenis kelamin laki-laki dan al-mar'ah/al-nisa untuk menyebut jenis kelamin perempuan.

\section{Tabel Perbedaan Seks dan Gender. ${ }^{7}$}

\begin{tabular}{|c|c|c|c|}
\hline No & Karakteristik & Seks & Gender \\
\hline 1 & $\begin{array}{l}\text { Sumber } \\
\text { Pembeda }\end{array}$ & Tuhan & Manusia (masyarakat) \\
\hline 2 & Visi, misi & Kesetaraan & Kebiasaan \\
\hline 3 & Unsur pembeda & $\begin{array}{l}\text { Biologis (alat } \\
\text { reproduksi) }\end{array}$ & $\begin{array}{l}\text { Kebudayaan } \\
\text { (tingkah laku) }\end{array}$ \\
\hline 4 & Sifat & $\begin{array}{l}\text { Kodrat, tertentu, } \\
\text { tidak dapat } \\
\text { dipertukarkan }\end{array}$ & $\begin{array}{l}\text { Harkat, martabat dapat } \\
\text { di pertukarkan }\end{array}$ \\
\hline 5 & Dampak & $\begin{array}{l}\text { Terciptanya nilai- } \\
\text { nilai kesempurnaan, } \\
\text { kenikmatan, } \\
\text { kedamaian dll. } \\
\text { sehingga } \\
\text { Menguntungkan } \\
\text { kedua belah pihak. }\end{array}$ & $\begin{array}{l}\text { Terciptanya norma- } \\
\text { norma/ketentuan } \\
\text { tentang "pantas" atau } \\
\text { tidak pantas" laki-laki } \\
\text { pantas menjadi } \\
\text { pemimpin, perempuan } \\
\text { pantas dipimpin dan } \\
\text { lain- lain, yang sering } \\
\text { merugikan salah satu } \\
\text { pihak, kebetulan } \\
\text { adalah perempuan }\end{array}$ \\
\hline
\end{tabular}

7 Trisakti Handayani dan Sugiarti, Konsep dan Teknik Penelitian Gender, (Malang: UMM Press. 2006), h. 6. 


\begin{tabular}{llll}
\hline 6 & Keberlakuan & $\begin{array}{l}\text { Sepanjang masa, } \\
\text { dimana saja, tidak } \\
\text { mengenal perbedaan } \\
\text { kelas }\end{array}$ & $\begin{array}{l}\text { Dapat berubah, } \\
\text { musiman dan berbeda } \\
\text { antarkelas }\end{array}$ \\
& & \\
\hline
\end{tabular}

Secara kodrat, memang diakui adanya perbedaan (distinction), bukan pembedaan (discrimination) antara laki-laki dengan perempuan, misalnya dalam aspek biologis, masingmasing mempunyai kelebihan dan kekurangan yang selanjutnya bersifat komplementer, saling mengisi dan melengkapi, seperti yang di sebutkan dalam al-Qur'an berikut:

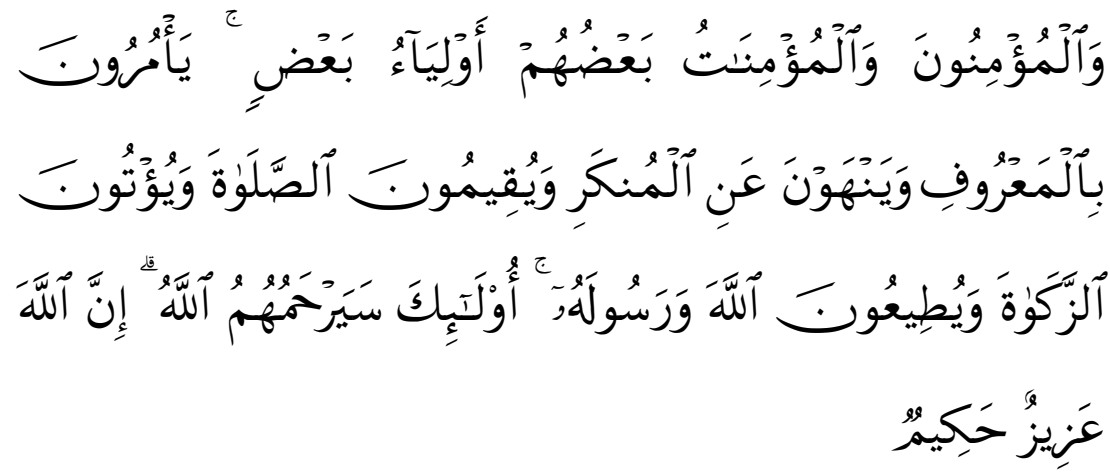

Artinya:

Dan orang-orang yang beriman, lelaki dan perempuan, sebahagian mereka (adalah) menjadi penolong bagi sebahagian yang lain. Mereka menyuruh (mengerjakan) yang ma'ruf, mencegah dari yang munkar, mendirikan shalat, menunaikan zakat dan mereka taat pada Allah dan Rasul-Nya. Mereka itu akan diberi rahmat oleh Allah; Sesungguhnya Allah Maha Perkasa lagi Maha Bijaksana. (Al-Taubah/9:71)

Ayat ini mengisyaratkan bahwa laki-laki dan perempuan seyogyanya melakukan kerja sama dalam amar ma'ruf dan nahi munkar. Maka sesuai dengan ayat itu, Islam tidak memisahkan antara kerja publik dan domestik. ${ }^{8}$ Al-Qur'an sebagai dasar utama dalam agama Islam, dipakai dasar rujukan seluruh kaum muslim 
dalam memperoleh petunjuk bimbingan, dan berkewajiban untuk mengamalkannya. Namun, al-Qur'an tidak berdiri sendiri, melainkan melibatkan ilmu-ilmu bantu di dalam memahaminya. Di antara ilmu bantu tersebut adalah tafsir.

\section{Keadilan dan Kesetaraan Gender}

Kajian gender lebih memperhatikan pada aspek maskulinitas (masculinity) atau feminitas (feminity) seseorang. ${ }^{8}$ Peran gender tidak berdiri sendiri melainkan terkait dengan identitas dan berbagai karakteristik yang diasumsikan masyarakat kepada laki-laki dan perempuan sebab terjadinya ketimpangan status antara laki-laki dan perempuan lebih dari sekedar perbedaan fisik biologis tetapi segenap nilai sosial budaya yang hidup dalam masyarakat turut memberikan andil. ${ }^{9}$

Perbedaan jenis kelamin melahirkan perbedaan gender dan perbedaan gender telah melahirkan berbagai ketidakadilan. Faktor yang menyebabkan ketidakadilan gender adalah akibat adanya gender yang dikonstruksikan secara sosial dan budaya. Ketidakadilan tersebut dikarenakan tidak terpenuhinya hak-hak dasar manusia bagi perempuan atau laki-laki. Hak yang dimaksud adalah hak untuk menentukan diri sendiri secara mandiri.

Ada beberapa definisi tentang keadilan dan kesetaraan gender yang diberikan oleh para penulis. Secara bahasa "keadilan" berasal dari kata dasar "adil" (just, fair, equitable, legal), yang berarti berpihak pada yang benar dan berpegang pada kebenaran, atau sifat, perbuatan dan perlakuan yang adil. Dalam kamus bahasa Indonesia kata "adil" yang berarti sama berat, tidak berat sebelah, tidak memihak. Sedangkan keadilan berarti sifat yang

8 Waryono Abdul G. dan Muh. Isnanto (eds), Isu-Isu Gender dalam Kurikulum Pendidikan Dasar dan Menengah, (Jogjakarta, PSW UIN SUKA dan IISEP, 2004), h. 8

9 Narasudin Umar, Argumen Kesetaraan Gender dalam Perspektif Alqur'an, (Jakarta: Paramadina. 1999), h. 75 
adil. "Kesetaraan" berasal dari kata "setara" (matcahing, equal) berarti sejajar (sama tingginya), sepadan, dan seimbang. ${ }^{10}$

Jadi keadilan gender berarti suatu proses dan perlakuan adil terhadap perempuan dan laki-laki. Dengan keadilan gender berarti tidak ada pembakuan peran, beban ganda, subordinasi, marginalisasi, dan kekerasan terhadap perempuan maupun lakilaki. Sedangkan kesetaraan gender adalah kesamaan kondisi bagi laki-laki dan perempuan untuk memperoleh kesampatan serta hak-haknya sebagai manusia.

Sedangkan keadilan dan kesetaraan gender yaitu terciptanya kesamaan kondisi dan status laki-laki dan perempuan untuk memperoleh kesempatan dan menikmati hak-haknya sebagai manusia agar sama-sama berperan aktif dalam pembangunan. Dengan kata lain, penilaian dari penghargaan yang sama oleh masyarakat terhadap persamaan dan perbedaan lakilaki dan perempuan serta pelbagai peran mereka. ${ }^{11}$

Keadilan gender mengantar perempuan dan laki-laki menuju kepada kesetaraan di mana kesamaan kondisi dan status untuk memperoleh kesempatan dan menikmati hak-haknya sebagai manusia agar mampu berperan dan berpartisipasi dalam pembangunan, politik, ekonomi, sosial, budaya, pendidikan, pertahanan dan keamanan dalam menikmati hasil pembanguan tersebut.

Ketidakadilan gender yang tersosialisasi kepada kaum laki-laki dan perempuan secara mantap akan mengakibatkan ketidakadilan tersebut merupakan kebiasaan dan akhirnya dipercaya bahwa peran gender itu seolah-olah merupakan kodrat dan akhirnya diterima masyarakat secara umum. Hal ini disebabkan karena terdapat kesalahan atau kerancuan makna gender. Karena pada dasarnya gender yang merupakan konstruksi

10 Departemen Pendidikan Nasional, Kamus Besar Bahasa Indonesia, (Jakarta: Balai Pustaka, 2005. Edisi ketiga), h. 8.

11 Hamdanah, Musim Kawin di Musim Kemarau; Studi Atas Pandangan Ulama Perempuan Jember Tentang Hak-Hak. (Jogjakarta: BIGRAF Publishing. 2005), h. 249. 
sosial, justru dianggap sebagai kodrat yang berarti ketentuan Tuhan. Misalnya pekerjaan domestik, seperti merawat anak, merawat rumah sangat melekat dengan tugas perempuan, yang akhirnya diangap kodrat. Padahal sebenarnya pekerjaan tersebut adalah konstruksi sosial yang dibentuk, sehingga dapat dipertukarkan atau dapat dilakukan baik laki-laki maupun perempuan.

Sesungguhnya perbedaan gender (gender different) tidaklah menjadi masalah sepanjang tidak melahirkan ketidakadilan gender (gender inequalities). Namun, persoalannya tidaklah sesederhana yang dipikirkan, ternyata perbedaan gender tersebut telah melahirkan berbagai ketidakadilan baik laki-laki maupun perempuan. Jadi ketidakadilan gender adalah suatu sistem dan struktur dimana kaum laki-laki dan perempuan menjadi korban dari sistem itu. Guna memahami bagaimana perbedaan gender telah berakibat pada ketidakadilan gender tersebut dapat dipahami melalui berbagai manifestasi ketidakadilan tersebut diantaranya yaitu; (a) proses marginalisasi dan pemiskinan terhadap kaum perempuan; (b) Subordinasi pekerjaan kaum perempuan; (c) Stereotip atas pekerjaan perempuan; (d) Kekerasan terhadap perempuan; (e) Beban kerja lebih berat. ${ }^{12}$

Misalkan kondisi tenaga kerja perempuan yang bekerja di luar negeri yang pasti tidak mempunyai daya tawar karena bekal pendidikan yang rendah. Dalam data statistik tahun 2007 tercatat tenaga kerja perempuan Indonesia di luar negeri berjumlah 70\% yang sebagian besar berusia muda dibawah 30 tahun dengan bekal pendidikan tidak tamat SD dan SMP.

Perempuan, bukan menerima saja kenyataan hidup. Kesalahan utama yang dilakukan para politisi, peneliti dan kaum feminis, adalah mereproduksi struktur patriarki dengan menekankan wacana ketimpangan gender, perempuan sebagai

12 Kementrian Negara Pemberdayaan Perempuan Republik Indonesia, Modul Pelatihan KKG Bagi Organisasi Masyarakat Keagamaan, (Jakarta: Deputi Bidang Pemberdayaan Lembaga Masyarakat, 2009), h. 41-42. 
mahluk lemah, tergantung dan halus. Dengan kata lain, melacak akar persoalan pendidikan berbias gender dimulai di keluarga, dilanjutkan di dunia pendidikan. Proses pembangunan terbukti telah memarginalkan perempuan. Proses marginalisasi ini berasal dari kebijakan pemerintah, keyakinan atau penafsiran ajaran agama, tradisi kebiasaan dan bahkan dari asumsi ilmu pengetahuan. ${ }^{13}$

Usaha yang harus dilakukan untuk mencapai kesetaraan gender nampaknya bukan hanya sekedar bersifat individual, namun harus secara bersama dan bersifat institusional, utamanya dari pihak-pihak yang memiliki kewenangan kekuasaan dan memegang peran dalam proses pembentukan gender. Untuk itu peranan pembuat kebijakan dan perencanaan pembangunan menjadi sangat penting dan menentukan arah perubahan menuju kesetaraan gender atau dapat dikatakan bahwa negara atau pemerintah mempunyai peran andil dalam mewujudkan keseimbangan gender. Dalam setiap perencanaan pembangunan, gender hendaknya dijadikan sebagai "kata kunci" dalam memahami kegiatan apa yang dilakukan laki-laki dan perempuan?, Berapa banyak waktu yang diperlukan untuk kegiatan tersebut?, Siapa yang memutuskan? dan sebagainya.

Terwujudnya kesetaraan gender dan keadilan gender ditandai dengan tidak adanya diskriminasi antara perempuan dan laki-laki, dengan demikian mereka memiliki (APKM) akses, kesempatan berpartisipasi, dan kontrol atas pembangunan serta memperoleh manfaat yang setara dan adil. Memiliki akses dan partisipasi berarti memiliki peluang atau kesempatan untuk menggunakan sumber daya dan memiliki wewenang untuk mengambil keputusan terhadap cara penggunaan dan hasil sumber daya tersebut. Memiliki kontrol berarti memiliki kewenangan penuh untuk mengambil keputusan atas penggunaan

13 Paulus Mujiran, Pernik-Pernik Pendidikan, Manifestasi dalam Keluarga, Sekolah dan Penyadaran Gender, (Jogjakarta: Pustaka Pelajar, 2002), h. 142. 
dan hasil sumber daya. Sehingga memperoleh manfaat yang sama dari pembangunan. Kebijakan pemerintah tentang gender harus disosialisasikan pada aspek pembangunan misalkan pendidikan, budaya, ekonomi, politik dan lain-lain.

3. Kebijakan dalam Pendidikan yang Berkeadilan dan Kesetaraan Gender

Dalam dunia pendidikan konsep gender terus bergulir untuk mencapai keseimbangan peran dan hak yang sama dalam memperoleh pendidikan. Namun hal itu tidak semulus harapan, disebabkan oleh budaya, pandangan dan ideologi patriarki, sehingga kecerdasan intelektual yang dimiliki perempuan sangat kurang dibandingkan laki-laki. ${ }^{14}$

Di bidang pembangunan pendidikan, UU No. 20 tahun 2003 tentang Sisdiknas menetapkan bahwa sistem pendidikan di Indonesia harus mampu menjamin pemerataan kesempatan pendidikan, peningkatan mutu dan relevansi dan efesiensi manajemen kebijakan. Pada bidang pembangunan pendidikan, Depdiknas juga telah menyusun kebijakan Nasional yaitu Pengarusutamaan gender (Inpres No 9 tahun 2000) dengan fokus utama untuk mengatasi kesenjangan gender di bidang pendidikan. Selain itu didukung oleh Deklarasi Universal HAM pada pasal 26 Pemerintah melalui Inspres No 9 tahun 2000 dan Keputusan Menteri Dalam Negeri Nomor 132 tahun 2003 menetapkan, bahwa pengarusutamaan gender sebagai strategi untuk mencapai kesetaraan dan keadilan gender (KKG) melalui pengintegrasian KKG dalam perencanaan, pelaksanaan, monitoring dan evaluasi kebijakan/program/kegiatan pembangunan. Selanjutnya, suatu kebijakan publik dipandang berspektif gender apabila:

a) Tujuan atau sasaran kebijakan telah ditetapkan untuk mewujudkan kesetaraan dan keadilan gender Berdasarkan

14 Nur Chayati, "Sekolah dan Spectrum Kesetaraan Gender, Aplikasi Androgini dan Kritik Proses Pembelajaran Di Sekolah", Edukasi, Vol II, (No 2 Desember 2004), h. 196. 
atas analisis situasi berdasarkan data terpilih menurut jenis kelamin

b) Menetapkan indikator-indiaktor gender pada setiap kebijakan pembangunan

c) Menetapkan rencana aksi yang ditujukan untuk mengurangi/ menghilangkan kesenjangan gender.

Dengan demikian suatu kebijakan pendidikan dikatakan berkualitas baik dalam perspektif gender apabila menetapkan tujuan/sasaran untuk memperkecil kesenjangan gender di bidang pendidikan. ${ }^{15}$ Kualitas kebijakan pendidikan dikategorikan dalam tiga klasifikasi yaitu netral gender, potensial bias gender, dan responsif gender. Suatu kebijakan dikatakan responsif gender apabila kebijakan/program/kegiatan tersebut sudah memperhitungkan kepentingan laki-laki dan perempuan. Suatu kebijakan dikatakan netral gender apabila kebijakan/program tersebut tidak memihak pada salah satu jenis kelamin. Suatu kebijakan dikatakan berpotensi bias gender apabila kebijakan/program tersebut terkesan netral gender, tetapi berpotensi untuk diimplementasikan secara bias gender (merugikan salah satu jenis kelamin). ${ }^{16}$ Komponen kunci keberhasilan integrasi perspektif gender dalam kebijakan pendidikan dipengaruhi oleh empat hal, yaitu kapasitas sumber daya manusia, capacity building/advokasi, budaya organisasi, jejaring serta kemitraan antar pihak yang berkompeten terhadap kesetaraan dan keadilan gender.

\section{Bias Gender dalam Pembelajaran Statistika}

Bias gender ini tidak hanya berlangsung dan disosialisasikan melalui proses serta sistem pembelajaran di Perguruan Tinggi, tetapi juga melalui pendidikan dalam lingkungan keluarga. Jika ibu atau pembantu rumah tangga (perempuan) yang selalu mengerjakan

15 Ismi Dwi Astuti Nurhaeni, Reformasi Kebijakan Pendidikan Menuju Kesetaraan dan Keadilan Gender, (Surakarta: LPP UNS Press, 2009), h. 135.

16 Ismi Dwi Astuti Nurhaeni, Reformasi Kebijakan Pendidikan... h. 15 
tugas-tugas domestik seperti memasak, mencuci, dan menyapu, maka akan tertanam di benak anak-anak bahwa pekerjaan domestik memang menjadi pekerjaan perempuan. Pembelajaran adalah proses interaktif peserta didik dengan pendidik dan sumber belajar pada lingkungan belajar. Sedangkan bias gender adalah suatu pandangan yang membedakan peran, kedudukan serta tanggung jawab laki-laki dan perempuan dalam kehidupan kelurga, masyarakat, dan pembangunan. Adapun yang bias gender adalah penerapan pembelajaran yang didalamnya dalam proses belajar mengajar memihak antara laki-laki dan perempuan dalam peran pembelajaran yang tidak seimbang.

Belajar merupakan suatu proses perubahan tingkah laku seseorang sebagai hasil dari interaksi dengan lingkungannya dalam memenuhi kebutuhan hidupnya. Perubahan-perubahan tersebut dinyatakan dalam suatu aspek tingkah laku. Pengertian belajar dapat didefinisikan sebagai suatu proses usaha yang dilakukan individu untuk memperoleh suatu perubahan tingkah laku yang baru secara keseluruhan, sebagai hasil pengalaman individu itu sendiri dalam interaksi dengan lingkungannya.

Perubahan yang diperoleh individu setelah melalui suatu proses belajar meliputi perubahan keseluruhan tingkah laku. Jika seseorang belajar sesuatu, sebagai hasilnyaia akan mengalami tingkah laku secara menyeluruh dalam sikap, ketrampilan dan pengetahuan. Belajar menurut Gredler adalah proses orang memperoleh berbagai kecakapan, ketrampilan,dan sikap. Untuk mengetahui hasil kegiatan belajar diperlukan suatu tes hasil belajar. Tes hasil belajar berupa tes yang disusun secara terencana untuk mengungkap performansi maksimal subyek dalam menguasai bahan-bahan atau materi yang telah diajarkan. Dalam kegiatan pendidikan formal di kelas, tes hasil belajar dapat berbentuk ulangan-ulangan harian, penugasan, ujian tengah semester (UTS) dan ujian akhir semester (UAS). Menurut Ausubel dalam Dahar belajar itu haruslah bermakna. Belajar bermakna 
merupakan suatu proses dikaitkannya informasi baru pada konsep-konsep relevan yang terdapat dalam struktur kognitif.

Belajar statistika merupakan bagaimana membangun konsep berfikir logis dengan memaksimalkan analisis yang tajam dalam membuat keputusan. Sehingganya bagi mahasiswa perempuan konsep berfikir tersebut sulit untuk dilakukan karena perempuan lebih mengedepankan pada komunikasi. Hal ini menyebabkan pencapaian belajar pada laki-laki lebih baik di bandingkan dengan perempuan.

\section{Kemampuan Belajar Statistika Laki-laki dan Perempuan}

Kemampuan atau kecakapan dapat dibagi ke dalam dua bagian yaitu kecakapan nyata (actual ability) dan kecakapan potensial (potential ability). Kecakapan nyata (actualability) yaitu kecakapan yang diperoleh melalui belajar (achivement atau prestasi), yang dapat segera didemonstrasikan dan diuji sekarang. Misalkan, setelah selesai mengikuti proses pembelajaran (kegiatan tatap muka di kelas), pada akhir pembelajaran siswa diuji oleh guru tentang materi yang disampaikannya (tesformatif). Ketika siswa mampu menjawab dengan baik tentang pertanyaan guru, maka kemampuan tersebut merupakan kecakapan nyata (chievement). Sedangkan kecakapan potensial merupakan aspek kecakapan yang masih terkandung dalam diri individu dan diperoleh dari faktor keturunan (herediter).

Kecakapan potensial dapat dibagi ke dalam dua bagian yaitu kecakapan dasar umum (Inteligensi atau kecerdasan) dan kecakapan dasar khusus (bakat atau aptitudes). Untuk mengukur bakat seseorang, dapat menggunakan beberapa instrumen standar, diantaranya: DAT (Differential Aptitude Test), SRA-PMA (Science Research Action-Primary Mental Ability), FACT (Flanagan Aptitude Calassification Test). Alat test ini dapat mengungkap tentang: (1) pemahaman kata; (2) kefasihan mengungkapkan kata; (3) pemahaman bilangan; (4) tilikan ruangan; (5) daya ingat; (6) kecepatan pengamatan; (7) berfikir logis; dan (8) kecakapan 
gerak. Terkait dengan proses pembelajaran, yang perlu menjadi perhatian bahwa antara satu individu dengan individu lainnya pada dasarnya memiliki kecakapan yang berbeda-beda, namun tidak berdasarkan pada kelaminnya.

Adapun tujuan pembelajaran statistika yaitu menata kemampuan pemahaman konsep matematis. Hal ini sesuai dengan rekomendasi oleh National Council of Teachers of Mathematics Standards bahwa salah satu komponen penting yang direkomendasi pada Casey adalah pengajaran konsep statistika yang merupakan induk dari staistika yang mengembangkan pemahaman pada logika berfikir. Pemahaman logika mencakup kemampuan untuk berpikir melalui transformasi gambar mental. Cara berpikir spatial berbeda dengan tipe proses informasi alternatif yang menunjukkan aktivitas berpikir deduktif-logis dan linear, yang diakses melalui sistem verbal. Kedua strategi ini dapat diterapkan pada penyelesaian soal-soal statistika. Misalnya, soal statistika dapat diselesaikan dengan menggambar diagram penyelesaian (solusi spatial) atau dengan membuat penyelesaian logika tahap demi tahap (penyelesaian logis-deduktif, verbal).

Satu faktor yang mendukung pengaruh mediasi berbagai tipe tugas mekanis spatial ini terkait dengan pilihan strategi penyelesaian- soal statistika yang lebih disukai anak laki-laki dibandingkan dengan strategi yang lebih disukai anak perempuan. Pada penelitian Tartre ditemukan bahwa siswa dengan skor tinggi pada tes ketrampilan verbal yang disertai dengan skor rendah pada tes visualisasi spatial menggunakan petunjuk verbal untuk menyelesaikan soal berbasis statistika, sedangkan siswa dengan pola kemampuan sebaliknya mengandalkan petunjuk gambar, visual. Sub-kelompok anak perempuan verbal-tinggi/spatialrendah memiliki skor statistika terendah dan merasa tertinggal sepanjang tahun. Kelompok ini merasa kesulitan mengubah informasi verbal menjadi bentuk gambar. Penelitian ini juga menemukan bukti perbedaan strategi yang digunakan anak lakilaki dan anak perempuan, bahkan untuk menyelesaikan soal 
spatial. Bukti ini menunjukkan bahwa anak laki-laki sebagai satu kelompok mengandalkan strategi spatial ketika menyelesaikan tugas rotasi-mental, sedangkan anak perempuan sebagai kelompok cenderung menggunakan strategi verbal untuk menyelesaikan tugas ini. Siswa yang memiliki fleksibilitas untuk mencoba strategi verbal atau spatial ketika menyelesaikan soal mungkin memiliki keunggulan khusus, jika item-item tidak dapat diselesaikan dengan algoritma dan pemodelan yang diingat.

\section{Perspektif Gender dalam Pembelajaran Statistika}

Keterlibatan perempuan sekarang dalam berbagai sektor publik tidak lagi dianggap tabu. Demikian pula peningkatan kualitas sumber daya perempuan semakin menunjukkan angkaangka yang lebih baik. Konsep pembangunan yang berwawasan gender telah dicanangkan, akibatnya setiap kebijaksanaan para pengambil keputusan harus memperhatikan unsur-unsur keadilan gender.

Berbagai peraturan telah dicanangkan sedemikian rupa, sehingga laki-laki dan perempuan mempunyai keseimbangan hak dan kewajiban setara, misalnya organisasi-organisasi kewanitaan, seperti Dharma Wanita, PKK, dan semacamnya yang semakin berkembang. Namun, kenyataan dalam masyarakat masih jauh dari yang diharapkan. Perkembangan masyarakat modern masih tetap mengadopsi warisan budaya bahwa laki-laki dianggap sebagai figur utama dan perempuan dianggap sebagai figur kedua atau biasa disebut dengan sistem kemasyarakatan patriarkhi, yaitu sistem masyarakat yang memandang laki-laki sebagai thefirstsex dan perempuan sebagai thesecondsex karena organ reproduksinya sewaktu-waktu dapat menjadi penghalang untuk berproduksi. System tersebut secara tidak langsung akan memengaruhi perkembangan statistika pada anak perempuan karena statistika dianggap sebagai mata pelajaran untuk laki-laki sehingga mengakibatkan persepsi statistika antara laki-laki dan 
perempuan juga berbeda, dan akhirnya mengakibatkan juga pada hasil belajar statistika antara laki- laki dan perempuan.

Dalam proses pembelajaran laki-laki lebih teliti dan serius dalam mengerjakan dan menyelesaikan masalah pada pembelajaran statistika dibandingkan perempuan. Hal senada di pertegas Orton bahwa adanya budaya yang masih menganut bahwa statistika merupakan pelajaran untuk laki-laki dan pelajaran tertentu lainnya untuk anak perempuan. Lebih lanjut Orton menjelaskan bahwa hal ini dapat dilihat banyak buku teks yang telah menyindir secara tidak langsung. Dengan adanya pernyataan tersebut menunjukan bahwa logoka berfikir laki-laki lebih baik dibandingkan dengan perempuan.

\section{Kesimpulan}

Budaya bias laki-laki membentuk perempuan cenderung nrimo, karenanya upaya sistematis dan berkelanjutan tentang kesetaraan dan keadilan gender dalam pendidikan menjadi semakin mendesak, akses pendidikan perempuan dan laki-laki harus mendapatkan kesempatan yang sama. Anak perempuan sebagaimana anak laki-laki harus mempunyai hak atau kesempatan untuk kampus lebih tinggi. Pendirian gender perlu diterjemahkan dalam aksi nyata berupa gerakan pembebasan yang bertanggung jawab, mendorong laki-laki dan perempuan untuk merubah tradisi pencerahan, yaitu sikap yang didasrkan pada akal, alam, manusia, agar diperoleh persamaan kebebasan dan kemajua bersama, tanpa membedakan jenis kelamin. Dalam pembelajaran statistika mahasiswa lebih aktif dan lebih mengembangkan pada berfikir logis sedangkan, mahasiswi lebih unggul dalam komunikasi.]

\section{Daftar Pustaka}

Abdul G., Waryono dan Isnanto, Muh. (eds), Isu-Isu Gender dalam Kurikulum Pendidikan Dasar dan Menengah, Yogyakarta, PSW UIN SUKA dan IISEP, 2004. 
Chayati, Nur. "Sekolah dan Spectrum Kesetaraan Gender, Aplikasi Androgini dan Kritik Proses Pembelajaran di Sekolah", Edukasi, vol II, No 2 Desember 2004.

Departemen Pendidikan Nasional, Kamus Besar Bahasa Indonesia, Jakarta: Balai Pustaka, 2005.

Echols, John M. dan Syadily, Hassan. Kamus Inggris Indonesia, Cet XII, Jakarta: Gramedia, 1993

Fakih, Mansour. Analisi Gender dan Transformasi Sosial, Pustaka Pelajar : Yogyakarta, 2006

Hamdanah, Musim Kawin di Musim Kemarau; Studi Atas Pandangan Ulama Perempuan Jember Tentang Hak-hak, Jogjakarta: BIGRAF Publishing, 2005.

House, Random. Webster College Dictionary, New York Toronto London Sydney Auckland, 2001.

Istibsyaroh, Hak-hak Perempuan Relasi Gender Menurut Tafsir AlSya'rawi, Jakarta: Teraju, 2004

Kementrian Negara Pemberdayaan Perempuan Republik Indonesia, Modul Pelatihan KKG Bagi Organisasi Masyarakat Keagamaan, Jakarta: Deputi Bidang Pemberdayaan Lembaga Masyarakat, 2009.

Muawanah, Elfi. Pendidikan Gender dan Hak Asasi Manusia, Yogyakarta: Teras, 2009

Muhdirahayu (terj), Dictionary of Feminist Theories, Yogyakarta: Fajar Pustaka Baru, 2002

Mujiran, Paulus. Pernik-pernik Pendidikan, Manifestasi dalam Keluarga, Sekolah dan Penyadaran Gender, Yogyakarta: Pustaka Pelajar, 2002. 
Muthia'in, Achnad. Bias Gender Dalam Pendidikan, Surakarta: UMS, 2001.

Narwoko, Dwi dan Yuryanto, Bagong. Sosiologi Teks Pengantar dan Terapan, Jakarta: Kencana Prenada Media Group, 2004

Nurhaeni, Ismi Dwi Astuti. Reformasi Kebijakan Pendidikan Menuju Kesetaraan dan Keadilan Gender, Surakarta: LPP UNS Press, 2009

Salim, Peter. The Contemporary English-Indonesian Dictionary, Jakarta: Modern English Press, 1996.

Sunarto, Kamanto. Pengantar Sosiologi Edisi Revisi, Jakarta: Lembaga Penerbit Fakultas Ekonomi, Universitas Indonesia, 2004

Suryadi, Acce. dan Acep Idris, Kesetaraan Gender dalam Bidang Pendidikan, Jakarta: PT Genesindo, 2004.

Tierney, Hellen (ed). Women's Studies Inclopedia, Vol I, New York: Green Word Press

Umar, Narasudin. Argumen Kesetaraan Gender dalam Perspektif AlQur'an, Jakarta: Paramadina. 1999. 